\title{
IMPACT OF IRRIGATION WATER MANAGEMENT AND SILICON SPRAYING ON AVOIDING COLD INJURY AND IMPROVEMENT YIELD OF KITT MANGOS
}

\author{
Gooda $^{1}$, A.S.; N. Abd El-Hamid ${ }^{1}$; A.F. Abo-Hadid ${ }^{1}$; O.A. El-Behari ${ }^{1}$ \\ and Samah I. Nasr ${ }^{2}$ \\ 1- Horticulture Dept., Fac. of Agric., Ain Shams Univ., Cairo, Egypt \\ 2- Higher Institute for Agriculture Co-Operation, Cairo, Egypt
}

Keywords: Irrigation water management; Potassium silicate; Kitt mongo; Cold injury; Vegetative; Growth; Chemical constituents; Fruit quality

\section{ABSTRACT}

The present study was carried out during 2015 and 2016 seasons on Kitt mongo trees to evaluate the effect of three irrigation water management (4000 m3 of irrigation water were applied to the four physiological stages of mango tree growth as $15 \& 20 \& 40 \& 25 \%, 30 \& 15 \& 35 \& 20 \%$ and $35 \& 20 \& 30 \& 15 \% \mathrm{~m}^{3} /$ tree/ year, respectively) as well as four concentrations of potassium silicate on avoiding cold injury and improvement yield of kitt mango .

Irrigation Mango tree by the second program water management $(30,15,35,20)$ recorded The highest values of vegetative growth in terms of number of shoot/tree and lower values of leaves percentage affected with cold injury, Also, an evident increase in the content leaves of $N$ \& $K$ elements , $\mathrm{C} / \mathrm{N}$ ratio and final fruit set $\%$ total yield by divided irrigation water at the four physiological stages of mango trees $(30,15,35,20)$ was recorded compared with the other two water managements. No significant differences between the second and third irrigation water management programs $(30 \%, 15 \%, 35 \%, 20 \%$ and $35 \%, 20 \%$, $30 \%, 15 \%$ ) on values of leaf area, P\% and total carbohydrates as well as on TSS, acidity and Lascorbic acid content of fruits .

Spraying trees with potassium silicate in three times during the period from October to January at the rate of $1000 \mathrm{ppm}$ give the highest values of quality characteristics at mango trees and their fruits. While sprayed with potassium silicate at 2000 ppm achieve moderate values of the mentioned characteristics

It could be recommended from the obtained data that irrigation water management at the four physiological stages $(30,15,35,20)$ of Kitt mango trees and spraying $1000 \mathrm{ppm}$ potassium silicate in dormancy period is considered a good treatment to avoid cold damage on leaves and fruits as well as in giving the highest yield and quality of kitt fruit.

\section{INTRODUCTION}

Mangoes (Mangifera indica L.) belong to family Anacardaceae. native to South Eastern Asia and considered one of the most important fruits of the tropical and sub tropical countries. Mango fruit is an abundant source of vitamins, minerals and is famous for its excellent flavour, attractive fragrance and nutritional value. It is as an emerging tropical export crop and is produced in about 90 countries in the world with a production of over 820,877 MT (Abbasi et al 2011)

Mango trees are one of the most important fruit trees, which succeed under upper Egypt conditions but high temperature degree increases evapo transpiration rate. Consequently, the amount of needed water by trees increases, especially at new reclaimed area of low water supply. Due to high temperatures of Egyptian region between (April and October) there exists very high water evaporation rate. Kiett mango cultivar grown successfully under the Egyptian conditions and its yield production comes in the late season. (Al-Rawahy et al 2011). 
Tropical and subtropical plants exhibit a distinct physiological damage when they are exposed at low temperatures below $10^{\circ} \mathrm{C}$ (Krause, 1994). This is referred to as 'chilling injury'. It is observed at temperatures above $0^{\circ} \mathrm{C}$ and is quite distinct from freezing injury. This is mainly associated with physical disorders caused by freezing of water. Although chilling injury can be induced in complete darkness, it is more marked under weak light Chilling injury in light is regarded as a kind of photoinhibition (Sonoike, 1998)

Chilling injury can occur under certain distinct characteristics of lower threshold temperature below which it is induced in the plant (Powles et al 1983 and Raison \& Brown, 1989). It causes damage to the chloroplast and affect photosynthetic activities which are irreversible in nature, and leads to reduction in the rate of photosynthesis. Thereafter, visible symptoms develop in the plants after several days of hidden chilling injury. Chilling injury may lead to indirect damage to plants. These may include starvation, in which the respiration rate may exceed the rate of photosynthesis, Chilling injuries were manifested in several forms in mango, litchi, guava and papaya (Chen and Paull 1986). Mango was the second most susceptible fruit plant, in spite of its wide adaptability to a range of elevations extending up to $1400 \mathrm{~m}$ asl. Mango needs an optimum temperature range of $24-26.7^{\circ} \mathrm{C}$ and minimum thresh-old temperature is $10-12^{\circ} \mathrm{C}$ below this plant shows chilling injury 10 . Stomatal density on mango leaves is high on the upper layer, making them susceptible to low temperatures (Lutze et al 2002) reported that a minimum temperature of $-0.6-0^{\circ} \mathrm{C}$ for $1 \mathrm{~h}$ and $15 \mathrm{~min}$ for two consecutive days resulted in significant damage to mango trees (Allen, and Ort, 2001)

Although being one of the few drought-tolerant plants, mango trees are irrigated to ensure optimum and consistent productivity. Fruiting period is considered to be the most sensitive period of water stress, water supply is the most critical during the first six weeks of the fruit developing process, drought will induce late-stage fruit drop and reduced fruit mass via decreased cell size and number (Singh, 2005). Irrigation is necessary because very little rainfall and even drought in the meantime can lead to the decline of yields and quality of the mangoes. Farmers have to irrigate mango trees to ensure high yields and good quality. Zaen Eldeen, et al 2015

Asuperior water-management program seeks to provide an optimal balance of water and air in the soil, which allows full expression of genetic potential in plants. The differences among poor, average, and record crop yields generally can be attributed to the amount and timing of the soil's water supply .Improving water management is an important way to increase crop yields. Drainage can increase soil surface temperatures during the early months of the growing season by 6 to $12^{\circ} \mathrm{F}$. Warmer temperatures assist germination and increase plant growth (Brouwer, et al 1985 and Davies et al 2000). Soil moisture and compaction can have a significant effect on temperature around the soil surface. A moist compact soil will store more (Hilhorst et al 2001). For this reason, avoid cultivation just before a frost event since a soil that is loose and dry can increase frost injury. Some growers rely on overhead sprinkler irrigation or misting for frost protection. The formation of ice gives off an exothermic reaction that actually creates heat. The heat released protects the plant from injury (Michelle, 2010).

The use of advanced water-saving irrigation techniques and measures can significantly reduce water consumption, improve agronomic water use efficiency, save labor and costs, reduce the adverse effects of agricultural water resource availability from climate change and relieve the crisis of water resource and so on (Kato et al (2009). Perdro et al (2003) observed that daily mango orchard evapotranspiration increased slowly from $3.1 \mathrm{~mm}$ per day at the beginning of the growth period to $4.9 \mathrm{~mm}$ per day at maximum growth period of the fruit .Then it decreased to reach a 4.1 $\mathrm{mm}$ per day value, approximately at the full maturation fruit at a semiarid region. The accumulated mango orchard water consumption for the whole productive cycle was 551.6 and $555.1 \mathrm{~mm}$.

Irrigation of mango trees can be beneficial, as it has been shown to reduce fruit drop resulting in satisfactory production (Hossain, 1994). However, bearing trees are often irrigated only after fruit set and thereafter at fortnight intervals, but not all growers practice this. Regular irrigation starting at fruit set prevented fruit drop and improved fruit in size and quality .The accuracy of management relates to the availability of information about the system water-soil-plant-atmosphere. Research has shown that the interruption of irrigation on mango crops during the flower differentiation is an interesting option; however, the irrigation should be restarted soon after, in the panicle emergence stage. [Santos and Martinez 2013).

Therefore, irrigation management plays a vital role in stabilizing production and facilitating the cultivation of these crops. Irrigation management 

injury and improvement yield of kitt mangos

for the mango crop must follow technical criteria, so that water is applied at the right time and the right amount (Mattar, 2007).

Silicon is the second most abundant constituent in the earth's crust (Ehrlich. 1981). It constitutes $27.7 \%$ of the total weight in soil after the oxygen (47\%) (Datnoff and Snyder (2001). Although silicon is not an essential plant nutrient, however, it is reported to increase the photosynthesis rate, the upright appearance and mechanical strength of plants, and also reduces the transpiration rate (Zhu and Gong, 2014). Studies on silicon mechanism of action studies suggest that this chemical element helps to induce plant defense mechanisms and it acts as a physical barrier by silicification of leaf cells (Rodrigues et al 2009).

Silicon (Si) has been proved to be beneficial for the healthy growth and development of many plant species, particularly from the Gramineae family (Marschner, 1995; Broadley et al 2011). Si application to crops has been reported to enhance their tolerance of multiple stresses (Guntzer, 2011), including pests and pathogens (Dallagnol et al 2012), metal toxicity (Rizwan et al 2012; Habibi, 2014), salt and water stress (Hattori et al 2005; Liu et al 2014).

The main role of potassium is the activation of many enzyme systems involved in the structure of organic substances and promotes photosynthesis and transport of the assimilates of the carbohydrates to the storage organs [Marschner 1986]. In addition, $\mathrm{K}$ is involved in several basic physiological functions. It resulted also in improving the fruit quality parameters, i.e., TSS\%, total sugars and coloration These effects might be dedicated to the potassium role in increasing tolerance to stresses and improving the formation and accumulation rates of sugars (Baiea et al 2015)

The main objective of this study was to provide rationale for water integrated management and spraying potassium silicate on avoiding cold injury and improvement yield as well as fruit quality of Kitt mango trees Waddi - Elnatron region.

\section{MATERIAL AND METHODS}

The present study was conducted during 2015 and 2016 seasons on Kitt mango trees in a private farm at Waddi - Elnatron region, Behira Governorate. The trees was 10 - year old and planted at $4.0 \times 2.5 \mathrm{~m} 2$ apart (420 tree/ fed) under drip irrigation system. uniform in size and in On -year bearing at first season of study . All horticultural practices including, pest management fertilization with macro and micro elements were done. A split plot design in 3 replicate was followed as experimental design where irrigation levels put in main plots and silicon spraying arranged in sub - main plot. The season of experiment in first year begin from Oct . 2014 till Oct 2015 and second year begin from Oct. 2015 till Oct. 2016. Two factors was studied in this research first is irrigation water management and second is spraying of silicon and their combination on avoiding cold injury and its effect on vegetative growth and yield of Kitt mango trees

Regarding irrigation water management ' it is regular with mango trees farmers to add irrigate water at rate of $4000 \mathrm{~m} 3$ of water / fed . Scheduling this amount on four physiological stages of the mango tree as follows:

1. The first phase (Oct.- Jan.), a critical period in the life of the mango tree where bud induction, initiation and differentiation occurred in this stage

2. The second phase (Jan. - April) the period of flowering and fruit set

3. The third stage (April - July) the period of fruit development is completed

4. The final stage (July - October) the period of fruit ripening and trees ready to enter into dormancy

It will be distributed the amount of irrigation water ( $4000 \mathrm{~m} 3 / \mathrm{fed})$ on the above mentioned physiological four stages as follows: -

1. $15 \%$ \& $20 \%$ \& $40 \%$ \& $25 \%$

2. $30 \% \& 15 \% \& 35 \% \& 20 \%$

3. $35 \% \& 20 \% \& 30 \% \& 15 \%$

Regarding spraying of silicon concentration of zero \& 500 \& 1000 and 2000 ppm during the dormancy period. (October, November and December) were sprayed one tree monthly. Experiment designed in 4 replicates, where irrigation program a arranged as main plot and silicon spraying as sub main plot .

3 irrigation programs $x 4$ silicon spray concentrations $=12$ treatments

12 Treatments $\times 4$ replicate $(1$ tree per each replicate) $=48$ trees for each season

The following measurements were recorded

\section{Vegetative growth}

Four main branches which were nearly uniform in growth, diameter and foliage density and distribution around the periphery of each tree were chosen and labeled in February, the following vegetative characters were measured.

- leaf area $\left(\mathrm{cm}^{2}\right)$ : was estimated by picking and weighing 30 full mature leaves and weighing 60 section of $1 \mathrm{~cm}^{2}$ (2 section of $1 \mathrm{~cm}^{2} /$ leaf), then 
the average leaf area $\left(\mathrm{cm}^{2}\right)=$ leaves weight $(\mathrm{g})$ $x 2$ section weight $(\mathrm{g})$.

- Average number of shoot/ tree

- Average leaves \% affected with cold injury

2. Leaf mineral status (N, P, K), shoot total carbohydrate and $\mathrm{C} / \mathrm{N}$ ratio

Leaves sample were picked from the $3^{\text {rd }}$ and $4^{\text {th }}$ node from shoot top at August 1st of the two seasons. The samples were washed, dried, grounded and digested according to (Nijjar, 1985) N, P, and $\mathrm{K}$ were determined in the digested solution as follows:

- Total nitrogen was determined as percentage using the micro-Kjeldahl method as described by wilde et al 1985).

- Phosphorus was estimated colorimetrically by the stannous chloride method as percentage according to (Truog and Meyer 1929)

- Potassium content was determined by Flame photometer as percentage according to method of (Jackson, 1973)

- Total carbohydrates content was determined in dried shoot powder as percentage according to Smith et al (1956)

\section{Final Fruit set (\%) and total Yield}

Ten distributed fruiting shoots around trees were chosen and labeled before the beginning of treatments. The number of flower per each shoot was count. Before harvest, the fruit retention for each branch was calculated as:

Fruit set Final (\%) = Total fruit number / total flower number

Total Yield: At harvesting time, the number of fruit per tree was counted and then, the yield per tree was calculated either fruit number or $\mathrm{Kg} /$ tree.

\section{Chemical fruit properties}

- For fruit quality determinations, (Total soluble solids \% ; Titratable acidity as $\mathrm{g}$ citric acid $/ 100 \mathrm{ml}$ juice ; and L- ascorbic acid content as $\mathrm{mg}$ $/ 100 \mathrm{ml}$, samples of three fruits were taken from each replicate to determine the pervious chemical properties as the methods described in (A.O.A.C. 2005).

All the obtained data were tabulated and statistically analyzed according to (Snedecor and Cocharn, 1980) using new L.S.R at $5 \%$ level for selecting the significant differences among treatment means

\section{RESULTS AND DISCUSSION}

\section{Vegetative growth parameters}

\subsection{Average leaf area $\left(\mathrm{cm}^{2}\right)$}

Data in Table (1) illustrated leaf area of Kitt mangos during the two studied seasons. However, irrigation 2 and 3 recorded highest values and were significantly similar in their effect on leaf area where irrigation No.1 recorded the least values of leaf area in both studied seasons. This data showed that divided water irrigation at $30,15,35$ and $20 \%$ (irrigation 2) or at $35,20,30$ and 15 (irrigation 3) has favorite effected in leaf area of kitt mango. Spraying 1000 ppm of silicon was effective than other concentrations or control an increasing leaf area which considered a good vegetables growth parameter to avoid fruit sunburn in Kitt mango However,2000 and 500 ppm were significantly similar in their effected on leaf area where as un sprayed trees recorded the least values of leaf area in both studied seasons.

Interaction between the two studied factors was significant in most cases for both studied seasons. Highest interaction values (81.5 and $80.9 \mathrm{~cm}^{2}$ ) were obtained by irrigation with program (2) and spraying silicon at $1000 \mathrm{ppm}$ in both seasons, respectively on the other hand, the least interaction values $(60.3$ and $53.6 \mathrm{~cm} 2)$ were recorded by irrigation No. 1 without silicon spraying.

\subsection{Average number of shoot/ tree}

It is clear from Table (2) that average number of shoot/ tree of Kitt mango greatly affected with both studied factors during 2015 and 2016 seasons. Highest number of shoot/tree was recorded by irrigation No $2(30,15,35,20 \%)$ followed by irrigation No $3(35,20,30,15 \%)$ no significant different were detected between irrigation No 2 and No 3 in the second season. Spraying silicon greatly increased number of shoot/tree than unsprayed trees in both studied seasons. However, the highest values were obtained with 500 at 1000 ppm without significant differences between them. Interaction between the two studied factors was significant in most cases, however in first season the interaction value (40.1 shoot/tree) was recorded by irrigation No 3 and spraying silicon at 1000 ppm. On the other hand, the least interaction value (31.4 shoot/tree) was obtained with irrigation 1 without silicon spraying. 

injury and improvement yield of kitt mangos

Table 1 . Effect of irrigation water management and Silicon spraying on leaf area $\left(\mathbf{c m}^{2}\right)$ of Kitt mango trees during 2015 and 2016 seasons

\begin{tabular}{|c|c|c|c|c|c|}
\hline \multirow{3}{*}{ Treatments } & \multicolumn{4}{|c|}{2015 Season } & \multirow{3}{*}{ Mean } \\
\hline & \multicolumn{4}{|c|}{ Silicon spraying PPm } & \\
\hline & Without & 500 & 1000 & 2000 & \\
\hline Irrigation 1 & $60.3 \mathrm{e}$ & $59.4 \mathrm{e}$ & $66.5 \mathrm{~d}$ & $68.4 \mathrm{~cd}$ & $63.65 \mathrm{~B}$ \\
\hline Irrigation 2 & $67.8 \mathrm{~cd}$ & $77.4 a b$ & $81.5 \mathrm{a}$ & $70.3 \mathrm{~cd}$ & $74.25 \mathrm{~A}$ \\
\hline Irrigation 3 & $64.3 \mathrm{de}$ & $71.5 \mathrm{c}$ & $76.2 \mathrm{~b}$ & $72.9 b c$ & $71.23 \mathrm{~A}$ \\
\hline \multirow[t]{2}{*}{ Mean } & $64.1 \mathrm{C}$ & $69.5 \mathrm{~B}$ & $74.7 \mathrm{~A}$ & $70.5 \mathrm{~B}$ & \\
\hline & \multicolumn{4}{|c|}{2016 Season } & \\
\hline Irrigation 1 & $53.6 \mathrm{f}$ & $54.7 \mathrm{f}$ & $64.3 d$ & $66.1 \mathrm{~d}$ & $59.68 \mathrm{~B}$ \\
\hline Irrigation 2 & 57.2 ef & $75.2 \mathrm{~b}$ & $80.9 a$ & $69.2 \mathrm{~cd}$ & $70.63 \mathrm{~A}$ \\
\hline Irrigation 3 & $58.4 \mathrm{e}$ & $69.9 \mathrm{~cd}$ & $77.2 \mathrm{ab}$ & $71.4 \mathrm{c}$ & $69.23 \mathrm{~A}$ \\
\hline Mean & $56.4 \mathrm{C}$ & $66.6 \mathrm{~B}$ & $74.1 \mathrm{~A}$ & $68.9 \mathrm{~B}$ & \\
\hline
\end{tabular}

Irrigation 1= $4000 \mathrm{~m} 3$ of irrigation water were applied as $15 \& 20 \& 40 \& 25 \%$ Irrigation $2=4000 \mathrm{m3}$ of irrigation water were applied as $30 \& 15 \& 35 \& 20 \%$ Irrigation $3=4000 \mathrm{~m} 3$ of irrigation water were applied as $35 \& 20 \& 30 \& 15 \%$ Values followed by the same letter (s) are not significantly different at $5 \%$ level

Table 2. Effect of irrigation water management and Silicon spraying on number of shoot /tree of Kitt mango trees during 2015 and 2016 seasons

\begin{tabular}{|c|c|c|c|c|c|}
\hline \multirow{3}{*}{ Treatments } & \multicolumn{4}{|c|}{2015 Season } & \multirow{3}{*}{ Mean } \\
\hline & \multicolumn{4}{|c|}{ Silicon spraying PPm } & \\
\hline & Without & 500 & 1000 & 2000 & \\
\hline Irrigation 1 & $31.4 f$ & 33.7 ef & 34.0 de & $35.1 \mathrm{de}$ & $33.55 \mathrm{C}$ \\
\hline Irrigation 2 & $34.5 \mathrm{de}$ & $41.3 \mathrm{ab}$ & $34.8 a b$ & $37.2 \mathrm{~cd}$ & $39.18 \mathrm{~A}$ \\
\hline Irrigation 3 & 32.6 ef & $39.5 \mathrm{bc}$ & $40.1 \mathrm{~b}$ & $36.5 \mathrm{~cd}$ & $37.20 \mathrm{~B}$ \\
\hline \multirow[t]{2}{*}{ Mean } & $32.8 \mathrm{C}$ & $38.2 \mathrm{~A}$ & $39.3 \mathrm{~A}$ & $36.3 \mathrm{~B}$ & \\
\hline & \multicolumn{4}{|c|}{2016 Season } & \\
\hline Irrigation 1 & $34.9 \mathrm{f}$ & 36.5 ef & 35.7 ef & $38.7 \mathrm{de}$ & $36.45 \mathrm{~B}$ \\
\hline Irrigation 2 & 37.5 ef & $46.5 \mathrm{a}$ & $48.7 \mathrm{a}$ & $43.5 \mathrm{bc}$ & 44.05 A \\
\hline Irrigation 3 & $38.1 \mathrm{de}$ & $45.7 \mathrm{ab}$ & $47.2 \mathrm{a}$ & $41.0 \mathrm{~cd}$ & $43.00 \mathrm{~A}$ \\
\hline Mean & $36.8 \mathrm{C}$ & $42.9 \mathrm{~A}$ & $43.9 \mathrm{~A}$ & 41.1 B & \\
\hline
\end{tabular}

Irrigation 1= $4000 \mathrm{~m} 3$ of irrigation water were applied as $15 \& 20 \& 40 \& 25 \%$ Irrigation $2=4000 \mathrm{m3}$ of irrigation water were applied as $30 \& 15 \& 35 \& 20 \%$ Irrigation $3=4000 \mathrm{m3}$ of irrigation water were applied as $35 \& 20 \& 30 \& 15 \%$ Values followed by the same letter (s) are not significantly different at $5 \%$ level

\subsection{Average leaves $\%$ affected with cold injury}

Date presented in Table (3) show that both irrigation water management and silicon spraying greatly affected cold injury \% appear on Kitt leaves, during 2015 and 2016 seasons. The least $\%$ of leaves which affected with cold injury were obtained with irrigation (30, 15, 35 and $20 \%$ ) in first season and irrigation by (35, 20, 30 and 15\%) in second season. However, no significant differences were recorded between irrigation No 2 and No 3 in second season. The obtained data declare that water irrigation management plays an important role in minimizing winter cold injury in Kitt mango which caused many damaged symptoms including death of trees. 
Table 3. Effect of irrigation water management and Silicon spraying on leaves percentage affected with cold injury of Kitt mango trees during 2015 and 2016 seasons

\begin{tabular}{|c|c|c|c|c|c|}
\hline \multirow{3}{*}{ Treatments } & \multicolumn{4}{|c|}{2015 Season } & \multirow{3}{*}{ Mean } \\
\hline & \multicolumn{4}{|c|}{ Silicon spraying PPm } & \\
\hline & Without & 500 & 1000 & 2000 & \\
\hline Irrigation 1 & $28.9 \mathrm{a}$ & $25.3 \mathrm{ab}$ & $18.9 \mathrm{de}$ & 16.7 ef & $22.45 \mathrm{~A}$ \\
\hline Irrigation 2 & $20.4 \mathrm{~cd}$ & $12.7 \mathrm{gh}$ & $10.2 \mathrm{~h}$ & $14.7 \mathrm{fh}$ & $14.50 \mathrm{C}$ \\
\hline Irrigation 3 & $22.5 \mathrm{bc}$ & $14.5 \mathrm{fg}$ & $13.1 \mathrm{gh}$ & $15.5 \mathrm{e}-\mathrm{g}$ & $16.4 \mathrm{~B}$ \\
\hline \multirow{2}{*}{ Mean } & $23.9 \mathrm{~A}$ & $17.5 \mathrm{~B}$ & $14.1 \mathrm{C}$ & $15.6 \mathrm{C}$ & \\
\hline & \multicolumn{4}{|c|}{2016 Season } & \\
\hline Irrigation 1 & $20.4 \mathrm{a}$ & $17.2 \mathrm{ab}$ & $14.9 \mathrm{bc}$ & $13.5 \mathrm{c}$ & $16.5 \mathrm{~A}$ \\
\hline Irrigation 2 & $17.7 \mathrm{ab}$ & $9.2 d-f$ & $7.6 \mathrm{f}$ & $11.3 \mathrm{~d}$ & $11.45 \mathrm{~B}$ \\
\hline Irrigation 3 & $16.8 \mathrm{bc}$ & 8.4 ef & $8.9 \mathrm{~d}-\mathrm{f}$ & $10.8 \mathrm{de}$ & $11.23 \mathrm{~B}$ \\
\hline Mean & 18.3 A & $11.6 \mathrm{~B}$ & $10.4 \mathrm{~B}$ & $10.9 \mathrm{~B}$ & \\
\hline
\end{tabular}

Irrigation 1= $4000 \mathrm{~m} 3$ of irrigation water were applied as $15 \& 20 \& 40 \& 25 \%$

Irrigation 2= $4000 \mathrm{~m} 3$ of irrigation water were applied as $30 \& 15 \& 35 \& 20 \%$

Irrigation $3=4000 \mathrm{~m} 3$ of irrigation water were applied as $35 \& 20 \& 30 \& 15 \%$

Values followed by the same letter (s) are not significantly different at $5 \%$ level

Spraying silicon at 500,1000 , or $2000 \mathrm{ppm}$ were effective in reducing average leaves $\%$ affected with cold injury during winter season compared with unsprayed trees .However, 1000 and $2000 \mathrm{ppm}$ of silicon were similar in their affect and recorded the least \% of affected leaves with cold injury in both seasons.. Interaction between the two studied factors was significant in most cases , the least values of affect cold injury leaves (10.2\%) was obtained by irrigation No 1 without silicon spraying.

Low temperature often show signs of water stress due to decreased root hydraulic conductance, leading to associated decreases in leaf water and turgorpotential, followed by a reduction of growth. (Sonobe et al 2011). Si can enhance antioxidant defense activity in plants under stress, resulting in decreased membrane oxidative damage, improved stability of cell membranes and enhanced stress tolerance (Waraich et al 2011 \& Abd-El-Rahman ).

During and after chilling, the rate of photosynthesis in the leaves of chilling sensitive plants decreased and this is more related to decreasing temperature and lengthening of chilling period and persisted for a long time after transfer of chilled plants in the heat (Boese et al 1997; Strauss et al 2007). The physiological reasons for the suppression of photosynthesis are the inhibition of phloem transport of carbohydrates from the leaves, sto- matal limitation, destruction of the photosynthetic apparatus, damage to water-splitting complex of photosysteml, inhibiting electrontransport, and uncoupling of electron transfer and energy storage, changes in the activity and inhibition of synthesis of key enzymes of the Calvin cycle and C4-way (Yoshida et al 1996 and Garstka et al 2007). Cold-sensitive crop species have smaller temperature homeostasis of leaf photosynthesis than cold tolerants pecies (Yamori et al 2009) and improving fruit quality (Epstein and Bloom, 2003). Water resource scarcity worldwide makes it necessary to understand the effects of water use reduction in more efficient and competitive crop irrigation. Even though mango is a drought resistant crop, fruit tree production plays an important role and the efficient use of water resources is mandatory. Cell enlargement and division need adequate water during fruit growth and development period, while lack of water inhibited fruit growth and development (Liu et al 2007).

\section{Chemical constituents}

\subsection{Leaves NPK constituents}

Data in Tables (4, 5 and 6 ) showed the effect of irrigation water managements and silicon spraying on leaf $\mathrm{N}, \mathrm{P}$ and $\mathrm{K}$ contents of Kitt mango trees during 2015\&2016 seasons. The highest values of leaf $\mathrm{N} \%(2.01$ and $1.93 \%)$ were obtained with 

injury and improvement yield of kitt mangos

irrigation $2(30,15,35$ and $20 \%)$ in both seasons, without significant differences between irrigation No 2 and No 3. No significant effect to silicon spraying was obtained on leaf $\mathrm{N} \%$ or control during the two studied seasons. Interaction between the two studied factors was significant in both studied seasons.

Slight effect was recorded by irrigation water No. 2 and No. 3 on were on leaf $P$ content of Kitt mango, however, irrigation No. 2 and No. 3 were similar in their effect on leaf $\mathrm{P}$ content in both studied seasons. All silicon spraying treatments increased leaf $P$ content of Kitt mango during the two studied seasons compared with control, but the great effect was recorded by 1000 ppm silicon. Interaction values were significant where the high interaction value of $\mathrm{P}(0.29 \%)$ was obtained with irrigation 3 and $100 \mathrm{ppm}$ silicon spraying in first season . However leaf $\mathrm{K}$ content was highest in first season with irrigation No.2 (30, 15, 35, $20 \%)$ and in second season with irrigation No.3 $(35,20,30$, $15 \%)$ no significant differences were detected between 1000 or 2000 ppm of silicon spraying in both seasons. However 500 ppm of silicon spraying exhibited similar values of leaf $K$ content with unsprayed trees in both seasons. Interaction between the two studied factors was significant in both studied seasons.

\subsection{Total carbohydrates and $\mathrm{C} / \mathrm{N}$ ratio}

\section{- Total carbohydrates}

Data in Table (7) show that shoot total carbohydrates $\%$ were high with irrigation program No.2 $(30,15,35$ and $20 \%)$ and irrigation $3(35,20,30$ and $15 \%$ ) without significant differences between them the least values of shoot total carbohydrates were recorded by irrigation program No.1 (15, 20, 40 and $25 \%$ ) in both studied seasons. Spraying silicon at 500 or 1000 ppm exhibited similar no significant values during the two studied seasons. Interaction between the two studied factors was significant in most cases, for instance, in the first season, the high value (40.4\%) was obtained with irrigation 2 and 1000 ppm silicon spraying. On contrary, the least value (26.4\%) was recorded by irrigation program No. 1 unsprayed trees.

\section{- $\mathrm{C} / \mathrm{N}$ ratio}

Additionally, it is clear from data in Table (8) that $\mathrm{C} / \mathrm{N}$ ratio greatly increasing with irrigation 2 (30, 15, 35 and $20 \%$ ) and irrigation program No $(35,20,30$ and $15 \%)$ with significant differences between them. However, the least value of $\mathrm{C} / \mathrm{N}$ ratio in both seasons were recorded by irrigation program No.1 (15, 20, 40, 25\%). Spraying silicon at all used concentrations greatly increased $\mathrm{C} / \mathrm{N}$ ratio than unsprayed trees, however, the great effect was more pronounced with 1000ppm of silicon spraying. Interaction between both studied factors showed that the highest interaction value of $\mathrm{C} / \mathrm{N}$ ratio (19.5) was recorded by irrigation program No. 2 and spraying silicon at1000 ppm. On contrary, the least values of $\mathrm{C} / \mathrm{N}$ ratio (14.2) was recorded by irrigation program No.1 without silicon spraying.

Increase water availability significantly increases flowering (Grattan et al 2006). This might be due to the increase carbohydrates content during flower differentiation as a result of the irrigation treatments.( Attalla, et al 2011).

Patumi, et al (2002). They showed that fruit tree productivity was increased with increasing irrigation level.

Si application increased plant growth significantly and increase drought tolerance in plants by maintaining plant water balance, photosynthetic activity, erectness of leaves and structure of xylem vessels under high transpiration rates (Melo et al 2003; Hattori et al 2005). Silicon application is reported to enhance leaf water potential under water stress conditions (Matoh et al 1991). $\mathrm{K} 2 \mathrm{SiO} 4$ gave the highest $\mathrm{K} \%$ values in faba bean plant tissue. (Abou-Baker et al 2011).

Recent studies suggest that silicon is beneficial in protecting the plants from all stresses through stimulating the expression of natural defense reaction and the production of phenolic compounds which act as antioxidants (Qin and Tian, 2009).

Silicon application was essential for stimulating growth and fruiting of different fruit crops (AlWasfy, 2013).

\section{Fruit set $\%$ and total yield (kg/tree)}

\section{- Final Fruit Set \%}

A great effect as shown in Table (9) to irrigation management on final fruit set \% especially with irrigation $2(30,15,35$ and $20 \%)$ in both studied seasons. whereas the least final fruit set \%was obtained with irrigation 1 (15, 20, 40 and 25\%) spraying silicon at 500,1000 or 2000 ppm were effective in increasing final fruit set than unsprayed one. No significant difference were detected between 500 or 2000 ppm silicon spraying in their effect on final fruit set \%. Interaction between the two studied factors was significant in both seasons. 
Table 4 . Effect of irrigation water management and Silicon spraying on leaf $\mathbf{N}$ percentage of Kitt mango trees during 2015 and 2016 seasons

\begin{tabular}{|c|c|c|c|c|c|}
\hline \multirow{3}{*}{ Treatments } & \multicolumn{4}{|c|}{2015 Season } & \multirow{3}{*}{ Mean } \\
\hline & \multicolumn{4}{|c|}{ Silicon spraying PPm } & \\
\hline & Without & 500 & 1000 & 2000 & \\
\hline Irrigation 1 & $1.85 \mathrm{c}$ & $1.87 \mathrm{bc}$ & $1.81 \mathrm{c}$ & $1.89 \mathrm{bc}$ & $1.86 \mathrm{~B}$ \\
\hline Irrigation 2 & $1.91 \mathrm{a}-\mathrm{c}$ & $2.11 \mathrm{a}$ & $2.07 \mathrm{ab}$ & $1.95 a-c$ & $2.01 \mathrm{~A}$ \\
\hline Irrigation 3 & $1.95 \mathrm{a}-\mathrm{c}$ & $2.00 a b$ & $1.94 \mathrm{a}-\mathrm{c}$ & $1.90 \mathrm{bc}$ & $1.95 \mathrm{AB}$ \\
\hline \multirow[t]{2}{*}{ Mean } & $1.90 \mathrm{~A}$ & $1.99 \mathrm{~A}$ & $1.94 \mathrm{~A}$ & $1.91 \mathrm{~A}$ & \\
\hline & \multicolumn{4}{|c|}{2016 Season } & \\
\hline Irrigation 1 & $1.80 a b$ & $1.75 \mathrm{~b}$ & $1.81 \mathrm{ab}$ & $1.75 b$ & $1.78 \mathrm{~B}$ \\
\hline Irrigation 2 & $1.88 \mathrm{ab}$ & $1.97 \mathrm{a}$ & $1.96 \mathrm{a}$ & $1.90 a b$ & $1.93 \mathrm{~A}$ \\
\hline Irrigation 3 & $1.85 \mathrm{ab}$ & $1.89 a b$ & $1.91 \mathrm{ab}$ & $1.88 a b$ & $1.88 \mathrm{AB}$ \\
\hline Mean & $1.84 \mathrm{~A}$ & $1.87 \mathrm{~A}$ & $1.89 \mathrm{~A}$ & $1.84 \mathrm{~A}$ & \\
\hline
\end{tabular}

Irrigation 1= $4000 \mathrm{~m} 3$ of irrigation water were applied as $15 \& 20 \& 40 \& 25 \%$ Irrigation $2=4000 \mathrm{~m} 3$ of irrigation water were applied as $30 \& 15 \& 35 \& 20 \%$ Irrigation $3=4000 \mathrm{~m} 3$ of irrigation water were applied as $35 \& 20 \& 30 \& 15 \%$ Values followed by the same letter (s) are not significantly different at $5 \%$ level

Table 5. Effect of water irrigation management and Silicon spraying on leaf $\mathbf{P}$ percentage of Kitt mango trees during 2015 and 2016 seasons

\begin{tabular}{|c|c|c|c|c|c|}
\hline \multirow{3}{*}{ Treatments } & \multicolumn{4}{|c|}{2015 Season } & \multirow{3}{*}{ Mean } \\
\hline & \multicolumn{4}{|c|}{ Silicon spraying PPm } & \\
\hline & Without & 500 & 1000 & 2000 & \\
\hline Irrigation 1 & $0.20 \mathrm{~d}$ & $0.20 \mathrm{~d}$ & $0.20 \mathrm{~d}$ & $0.23 \mathrm{~cd}$ & $0.21 \mathrm{~B}$ \\
\hline Irrigation 2 & $0.21 \mathrm{~d}$ & $0.25 \mathrm{bc}$ & $0.27 \mathrm{ab}$ & $0.22 \mathrm{~cd}$ & $0.24 \mathrm{~A}$ \\
\hline Irrigation 3 & $0.20 \mathrm{~d}$ & $0.26 a b$ & $0.29 \mathrm{a}$ & $0.21 \mathrm{~d}$ & $0.24 \mathrm{~A}$ \\
\hline \multirow[t]{2}{*}{ Mean } & $0.20 \mathrm{C}$ & $0.24 \mathrm{~A}$ & $0.25 \mathrm{~A}$ & $0.22 \mathrm{~B}$ & \\
\hline & \multicolumn{4}{|c|}{2016 Season } & \\
\hline Irrigation 1 & $0.20 \mathrm{c}$ & $0.21 \mathrm{c}$ & $0.24 a b$ & $0.23 \mathrm{~b}$ & 0.22 B \\
\hline Irrigation 2 & $0.20 \mathrm{c}$ & $0.24 a b$ & $0.26 \mathrm{a}$ & $0.23 \mathrm{~b}$ & $0.23 \mathrm{AB}$ \\
\hline Irrigation 3 & $0.23 \mathrm{~b}$ & $0.24 a b$ & $0.25 \mathrm{a}$ & $0.22 \mathrm{bc}$ & $0.24 \mathrm{~A}$ \\
\hline Mean & $0.21 \mathrm{C}$ & $0.23 \mathrm{~B}$ & $0.25 \mathrm{~A}$ & $0.23 \mathrm{~B}$ & \\
\hline
\end{tabular}

Irrigation $1=4000 \mathrm{~m} 3$ of irrigation water were applied as $15 \& 20 \& 40 \& 25 \%$ Irrigation 2= $4000 \mathrm{~m} 3$ of irrigation water were applied as $30 \& 15 \& 35 \& 20 \%$ Irrigation $3=4000 \mathrm{~m} 3$ of irrigation water were applied as $35 \& 20 \& 30 \& 15 \%$ Values followed by the same letter (s) are not significantly different at $5 \%$ level 
Table 6. Effect of irrigation water management and Silicon spraying on leaf $\mathbf{K}$ percentage of Kitt mango trees during 2015 and 2016 seasons

\begin{tabular}{|c|c|c|c|c|c|}
\hline \multirow{3}{*}{ Treatments } & \multicolumn{4}{|c|}{2015 Season } & \multirow{3}{*}{ Mean } \\
\hline & \multicolumn{4}{|c|}{ Silicon spraying PPm } & \\
\hline & Without & 500 & 1000 & 2000 & \\
\hline Irrigation 1 & $1.71 \mathrm{c}$ & $1.70 \mathrm{c}$ & $1.75 \mathrm{c}$ & 1.77 bc & $1.73 \mathrm{~B}$ \\
\hline Irrigation 2 & $1.76 \mathrm{c}$ & $1.74 \mathrm{c}$ & $1.89 a b$ & $1.92 \mathrm{a}$ & $1.83 \mathrm{~A}$ \\
\hline Irrigation 3 & $1.71 \mathrm{c}$ & $1.71 \mathrm{c}$ & $1.85 a b$ & $1.80 \mathrm{bc}$ & $1.77 \mathrm{~B}$ \\
\hline \multirow[t]{2}{*}{ Mean } & $1.73 \mathrm{~B}$ & $1.71 \mathrm{~B}$ & $1.83 \mathrm{~A}$ & $1.83 \mathrm{~A}$ & \\
\hline & \multicolumn{4}{|c|}{2016 Season } & \\
\hline Irrigation 1 & $1.70 \mathrm{~d}$ & $1.75 \mathrm{~cd}$ & $1.70 \mathrm{~d}$ & $1.73 \mathrm{~cd}$ & $1.72 \mathrm{~B}$ \\
\hline Irrigation 2 & $1.76 \mathrm{~cd}$ & $1.82 \mathrm{bc}$ & $1.91 \mathrm{ab}$ & $1.96 \mathrm{a}$ & $1.86 \mathrm{~A}$ \\
\hline Irrigation 3 & $1.82 \mathrm{bc}$ & $1.80 \mathrm{bc}$ & $1.94 \mathrm{a}$ & $1.93 \mathrm{a}$ & $1.87 \mathrm{~A}$ \\
\hline Mean & $1.76 \mathrm{~B}$ & $1.79 \mathrm{~B}$ & $1.85 \mathrm{~A}$ & $1.87 \mathrm{~A}$ & \\
\hline
\end{tabular}

Irrigation 1= $4000 \mathrm{~m} 3$ of irrigation water were applied as $15 \& 20 \& 40 \& 25 \%$ Irrigation 2= $4000 \mathrm{m3}$ of irrigation water were applied as $30 \& 15 \& 35 \& 20 \%$ Irrigation $3=4000 \mathrm{~m} 3$ of irrigation water were applied as $35 \& 20 \& 30 \& 15 \%$ Values followed by the same letter (s) are not significantly different at $5 \%$ level

Table 7. Effect of irrigation water management and Silicon spraying on Total Carbohydrates of Kitt mango trees during 2015 and 2016 seasons

\begin{tabular}{|c|c|c|c|c|c|}
\hline \multirow{3}{*}{ Treatments } & \multicolumn{4}{|c|}{2015 Season } & \multirow{3}{*}{ Mean } \\
\hline & \multicolumn{4}{|c|}{ Silicon spraying PPm } & \\
\hline & Without & 500 & 1000 & 2000 & \\
\hline Irrigation 1 & $26.4 \mathrm{f}$ & 28.3 ef & $29.6 \mathrm{de}$ & 30.7 c-e & $28.8 \mathrm{~B}$ \\
\hline Irrigation 2 & $29.5 \mathrm{de}$ & $37.5 a b$ & $40.4 \mathrm{a}$ & $32.9 \mathrm{~cd}$ & $35.1 \mathrm{~A}$ \\
\hline Irrigation 3 & $30.1 \mathrm{de}$ & $36.3 \mathrm{~b}$ & $36.1 \mathrm{~b}$ & $33.2 \mathrm{c}$ & $33.9 \mathrm{~A}$ \\
\hline \multirow[t]{2}{*}{ Mean } & $28.7 \mathrm{C}$ & $34.0 \mathrm{~A}$ & $35.4 \mathrm{~A}$ & $32.3 \mathrm{~B}$ & \\
\hline & \multicolumn{4}{|c|}{2016 Season } & \\
\hline Irrigation 1 & $27.2 \mathrm{f}$ & 29.7 ef & $31.1 \mathrm{e}$ & 32.6 de & $30.2 \mathrm{~B}$ \\
\hline Irrigation 2 & $31.1 \mathrm{e}$ & $39.8 \mathrm{~b}$ & $43.7 \mathrm{a}$ & $35.1 \mathrm{~cd}$ & $37.4 \mathrm{~A}$ \\
\hline Irrigation 3 & $32.0 \mathrm{de}$ & $39.1 \mathrm{~b}$ & $38.2 \mathrm{bc}$ & $36.3 \mathrm{c}$ & $36.4 \mathrm{~A}$ \\
\hline Mean & $30.1 \mathrm{C}$ & $36.2 \mathrm{~A}$ & $37.7 \mathrm{~A}$ & $34.7 \mathrm{~B}$ & \\
\hline
\end{tabular}

Irrigation 1= $4000 \mathrm{~m} 3$ of irrigation water were applied as $15 \& 20 \& 40 \& 25 \%$ Irrigation 2= $4000 \mathrm{m3}$ of irrigation water were applied as $30 \& 15 \& 35 \& 20 \%$ Irrigation $3=4000 \mathrm{~m} 3$ of irrigation water were applied as $35 \& 20 \& 30 \& 15 \%$ Values followed by the same letter (s) are not significantly different at $5 \%$ level 
Table 8. Effect of water irrigation management and Silicon spraying on $\mathbf{C} / \mathbf{N}$ ratio of Kitt mango trees during 2015 and 2016 seasons

\begin{tabular}{|c|c|c|c|c|c|}
\hline \multirow{3}{*}{ Treatments } & \multicolumn{4}{|c|}{2015 Season } & \multirow{3}{*}{ Mean } \\
\hline & \multicolumn{4}{|c|}{ Silicon spraying PPm } & \\
\hline & Without & 500 & 1000 & 2000 & \\
\hline Irrigation 1 & $14.2 \mathrm{e}$ & $15.1 \mathrm{de}$ & $16.3 \mathrm{~cd}$ & $16.2 \mathrm{~cd}$ & $15.5 \mathrm{~B}$ \\
\hline Irrigation 2 & 15.4 de & $17.8 \mathrm{~b}$ & $19.5 \mathrm{a}$ & $16.9 \mathrm{bc}$ & $17.4 \mathrm{~A}$ \\
\hline Irrigation 2 & $15.4 \mathrm{de}$ & $18.2 b$ & $18.6 \mathrm{~b}$ & $17.4 \mathrm{bc}$ & $17.4 \mathrm{~A}$ \\
\hline \multirow[t]{2}{*}{ Mean } & $15.0 \mathrm{C}$ & $17.0 \mathrm{~B}$ & $18.1 \mathrm{~A}$ & $16.8 \mathrm{~B}$ & \\
\hline & \multicolumn{4}{|c|}{2016 Season } & \\
\hline Irrigation 1 & $15.1 \mathrm{f}$ & $17.0 \mathrm{de}$ & $17.2 \mathrm{de}$ & $18.6 \mathrm{c}$ & $17.0 \mathrm{~B}$ \\
\hline Irrigation 2 & $16.5 \mathrm{e}$ & 20.2 b & $22.3 \mathrm{a}$ & $18.5 \mathrm{~cd}$ & $19.4 \mathrm{~A}$ \\
\hline Irrigation 2 & $17.3 \mathrm{de}$ & 20.7 b & $20.0 \mathrm{~b}$ & $19.3 \mathrm{bc}$ & $19.3 \mathrm{~A}$ \\
\hline Mean & $16.3 \mathrm{C}$ & 19.3 AB & $19.8 \mathrm{~A}$ & $18.8 \mathrm{~B}$ & \\
\hline
\end{tabular}

Irrigation 1= $4000 \mathrm{m3}$ of irrigation water were applied as $15 \& 20 \& 40 \& 25 \%$

Irrigation 2= $4000 \mathrm{~m} 3$ of irrigation water were applied as $30 \& 15 \& 35 \& 20 \%$

Irrigation $3=4000 \mathrm{~m} 3$ of irrigation water were applied as $35 \& 20 \& 30 \& 15 \%$

Values followed by the same letter (s) are not significantly different at $5 \%$ level

Table 9. Effect of irrigation water management and Silicon spraying on Final fruit set of Kitt mango trees during 2015 and 2016 seasons

\begin{tabular}{|c|c|c|c|c|c|}
\hline \multirow{3}{*}{ Treatments } & \multicolumn{4}{|c|}{2015 Season } & \multirow{3}{*}{ Mean } \\
\hline & \multicolumn{4}{|c|}{ Silicon spraying PPm } & \\
\hline & Without & 500 & 1000 & 2000 & \\
\hline Irrigation 1 & $1.54 f$ & 1.72 ef & $1.81 \mathrm{~d}-\mathrm{f}$ & $1.97 \mathrm{c}-\mathrm{e}$ & $1.76 \mathrm{C}$ \\
\hline Irrigation 2 & $1.75 d-f$ & $2.31 \mathrm{ab}$ & $2.58 \mathrm{a}$ & $2.11 \mathrm{bc}$ & $2.19 \mathrm{~A}$ \\
\hline Irrigation 3 & $1.73 \mathrm{~d}-\mathrm{f}$ & $2.24 \mathrm{bc}$ & $2.17 \mathrm{bc}$ & $2.03 b-d$ & $\begin{array}{l}2.04 \mathrm{~B} \\
0.93 \mathrm{~B} \\
1.23 \mathrm{~A} \\
1.12 \mathrm{~A}\end{array}$ \\
\hline \multirow[t]{2}{*}{ Mean } & $1.67 \mathrm{C}$ & $2.09 \mathrm{~B}$ & $2.19 \mathrm{~A}$ & 2.04 B & \multirow{6}{*}{$\begin{array}{l}0.93 \mathrm{~B} \\
1.23 \mathrm{~A} \\
1.12 \mathrm{~A}\end{array}$} \\
\hline & \multicolumn{4}{|c|}{2016 Season } & \\
\hline Irrigation 1 & $0.85 \mathrm{e}$ & $0.88 \mathrm{e}$ & 0.94 de & $1.03 \mathrm{de}$ & \\
\hline Irrigation 2 & 0.89 e & $1.36 \mathrm{ab}$ & $1.55 \mathrm{a}$ & $1.10 \mathrm{~cd}$ & \\
\hline Irrigation 3 & $0.93 \mathrm{de}$ & $1.17 \mathrm{bc}$ & $1.30 \mathrm{a}-\mathrm{c}$ & $1.06 \mathrm{c}-\mathrm{e}$ & \\
\hline Mean & $0.89 \mathrm{C}$ & $1.14 \mathrm{~B}$ & $1.26 \mathrm{~A}$ & $1.06 \mathrm{~B}$ & \\
\hline
\end{tabular}

Irrigation 1= $4000 \mathrm{~m} 3$ of irrigation water were applied as $15 \& 20 \& 40 \& 25 \%$

Irrigation 2= $4000 \mathrm{~m} 3$ of irrigation water were applied as $30 \& 15 \& 35 \& 20 \%$

Irrigation $3=4000 \mathrm{m3}$ of irrigation water were applied as $35 \& 20 \& 30 \& 15 \%$

Values followed by the same letter (s) are not significantly different at $5 \%$ level

\section{- Total Yield (kg / Tree)}

Data obtained in Table (10) showed that irrigation program No.2 (30, 15, 35 and $20 \%$ ) produced highest total yield in first season follow by irrigation $3(35,20,30$ and $15 \%)$ whereas irrigation program No.1 (15, 20, 40 and 25\%) came later. However , all silicon sprayers produced high total yield than unsprayed trees at the highest values of total yield was obtained with $1000 \mathrm{ppm}$ followed by 2000 ppm whereas 500 ppm came later. High interaction value of total yield $(18.18 \mathrm{~kg} /$ tree) was ob- tained in first season by irrigation program No.2 and $1000 \mathrm{ppm}$ silicon spraying .However, least total yield interaction value $(11.50 \mathrm{~kg} /$ tree) was recorded by irrigation 1 without silicon spraying.

Spraying (Silicon) at $5 \%$ as antitranspiration and irrigate plants at $60 \%$ of the available water depletion is the promising treatment to reduce the total amount of irrigated water through the growing season of Young Mango Trees. Besides, increased growth parameters and improved yield weight and fruit characteristics. (Zaen El-deen et al 2015). 

injury and improvement yield of kitt mangos

Table 10. Effect of irrigation water management and Silicon spraying on yield $\mathbf{k g} /$ tree of Kitt mango trees during 2015 and 2016 seasons

\begin{tabular}{|c|c|c|c|c|c|}
\hline \multirow{3}{*}{ Treatments } & \multicolumn{4}{|c|}{2015 Season } & \multirow{3}{*}{ Mean } \\
\hline & \multicolumn{4}{|c|}{ Silicon spraying PPm } & \\
\hline & Without & 500 & 1000 & 2000 & \\
\hline Irrigation 1 & $11.50 \mathrm{~d}$ & $12.37 \mathrm{~cd}$ & $12.50 \mathrm{~cd}$ & $12.80 \mathrm{~cd}$ & $12.30 \mathrm{~B}$ \\
\hline Irrigation 2 & $11.72 \mathrm{~d}$ & $16.14 \mathrm{~b}$ & $18.18 \mathrm{a}$ & $13.06 \mathrm{~cd}$ & $14.78 \mathrm{~A}$ \\
\hline Irrigation 3 & $12.35 \mathrm{~cd}$ & $14.30 \mathrm{bc}$ & $15.86 b$ & $13.58 \mathrm{c}$ & $14.02 \mathrm{~A}$ \\
\hline \multirow[t]{2}{*}{ Mean } & $11.86 \mathrm{C}$ & $14.27 \mathrm{~B}$ & $15.51 \mathrm{~A}$ & $13.15 \mathrm{~B}$ & \\
\hline & \multicolumn{4}{|c|}{2016 Season } & \\
\hline Irrigation 1 & $5.60 \mathrm{e}$ & $6.00 \mathrm{de}$ & $7.63 \mathrm{~b}$ & $8.18 b$ & $6.85 \mathrm{~B}$ \\
\hline Irrigation 2 & 5.70 de & $7.97 \mathrm{~b}$ & $9.26 \mathrm{a}$ & $7.58 \mathrm{bc}$ & $7.72 \mathrm{~A}$ \\
\hline Irrigation 3 & $6.61 \mathrm{~cd}$ & $8.02 \mathrm{~b}$ & $8.45 a b$ & $8.48 a b$ & $7.89 \mathrm{~A}$ \\
\hline Mean & $5.97 \mathrm{C}$ & $7.33 \mathrm{~B}$ & 8.45 AB & $8.08 \mathrm{~A}$ & \\
\hline
\end{tabular}

Irrigation $1=4000 \mathrm{~m} 3$ of irrigation water were applied as $15 \& 20 \& 40 \& 25 \%$ Irrigation 2= $4000 \mathrm{~m} 3$ of irrigation water were applied as $30 \& 15 \& 35 \& 20 \%$ Irrigation $3=4000 \mathrm{m3}$ of irrigation water were applied as $35 \& 20 \& 30 \& 15 \%$ Values followed by the same letter (s) are not significantly different at $5 \%$ level

Fruit growth is slow at early stage, grows faster at rapidly expansion stage, slowing down at mature stage during the whole fruit growth cycle with one growth peak. Soil water content is essential to the early development of mango fruit. Water supply is the most critical during the first 42 days of fruit development, drought can induce late-stage fruit dropping and reduce fruit mass via decreased cell size and number (Singh, 2005) There is a negative correlation between the number of fruits on the tree and the average fruit weight. Trends of fruit length, diameter and fruit shape index are identical between different treatments during the fruit development period. Irrigation has no significant effect on the fruit development, similar to the results of previous studies Caspari et al 1994 \& Liu et al 2007).

\section{Chemical fruit properties}

\section{- $\mathrm{SSC} \%$}

It is clear from data in Table (11) that both irrigation $2(30,15,35$ and 20\%) and $3(35,20,15)$ were similar in their effect on SSC \% in Kitt mango fruit and superior than irrigation $1(15,20,40$ and $25 \%$ ) in both seasons. All Concentrations of silicon increasing SSC \% in Kitt mango than unsprayed fruits, with non- significant differences between the three used concentrations of silicon. Interaction between the two studied factors was significant in most cases, the highest interaction value (17.6\%) in first season was obtained with irrigation program
No. 2 and 1000 ppm silicon spraying. The least interaction value (15.3\%) was recorded by irrigation program No.1 without silicon spraying.

\section{- Total Acidity \%}

Data in Table (12) show that no significant differences were recorded between the three water irrigation managements in their effect on total acidity \% in both studied seasons. Also, the same finding was also obtained concerning silicon spraying where no significant differences between different concentrations of silicon or control were detected. Interaction between the two studied factors was negligible and out of significant in both studied seasons.

\section{- Ascorbic acid}

Date presented in Table (13) show that both irrigation water management and silicon spraying greatly affected on ascorbic acid, during 2015 and 2016 seasons. The highest values ascorbic acid (51.85 and $51.93 \mathrm{mg} / 100 \mathrm{~g}$ F.wt.) were obtained with irrigation $2(30,15,35$ and $20 \%)$ in both seasons, without significant differences between irrigation No 2 and No 3. All silicon sprayers treatments increased ascorbic acid contents of Kitt mongo during the two studied seasons compared with control, the great effect recorded with $1000 \mathrm{ppm}$ followed by $2000 \mathrm{ppm}$ whereas 500 ppm came later. 
Table 11. Effect of irrigation water management and Silicon spraying on SSC \% of Kitt mango trees during 2015 and 2016 seasons

\begin{tabular}{|c|c|c|c|c|c|}
\hline \multirow{3}{*}{ Treatments } & \multicolumn{4}{|c|}{2015 Season } & \multirow{3}{*}{ Mean } \\
\hline & \multicolumn{4}{|c|}{ Silicon spraying PPm } & \\
\hline & Without & 500 & 1000 & 2000 & \\
\hline Irrigation 1 & $15.3 \mathrm{c}$ & $15.5 c$ & $16.0 \mathrm{c}$ & $16.4 \mathrm{bc}$ & $15.8 \mathrm{~B}$ \\
\hline Irrigation 2 & $16.2 \mathrm{bc}$ & $17.3 a b$ & $17.6 \mathrm{a}$ & $17.1 \mathrm{ab}$ & $17.1 \mathrm{~A}$ \\
\hline Irrigation 3 & $16.3 \mathrm{bc}$ & $17.2 \mathrm{ab}$ & $16.9 \mathrm{ab}$ & $17.2 a b$ & $16.9 \mathrm{~A}$ \\
\hline \multirow[t]{2}{*}{ Mean } & $15.9 \mathrm{~B}$ & 16.7 A & $16.8 \mathrm{~A}$ & $16.9 \mathrm{~A}$ & \\
\hline & \multicolumn{4}{|c|}{2016 Season } & \\
\hline Irrigation 1 & $16.0 \mathrm{c}$ & $16.3 \mathrm{bc}$ & $16.6 \mathrm{bc}$ & $16.5 \mathrm{bc}$ & $16.4 \mathrm{~B}$ \\
\hline Irrigation 2 & $16.6 \mathrm{bc}$ & $17.1 \mathrm{ab}$ & $17.3 \mathrm{ab}$ & $17.7 \mathrm{a}$ & $17.2 \mathrm{~A}$ \\
\hline Irrigation 3 & $16.5 \mathrm{bc}$ & $17.5 a b$ & $18.1 \mathrm{a}$ & $17.8 \mathrm{a}$ & $17.5 \mathrm{~A}$ \\
\hline Mean & $16.4 \mathrm{~B}$ & $17.2 \mathrm{~A}$ & $17.3 \mathrm{~A}$ & $17.3 \mathrm{~A}$ & \\
\hline
\end{tabular}

Irrigation $1=4000 \mathrm{~m} 3$ of irrigation water were applied as $15 \& 20 \& 40 \& 25 \%$ Irrigation $2=4000 \mathrm{~m} 3$ of irrigation water were applied as $30 \& 15 \& 35 \& 20 \%$ Irrigation $3=4000 \mathrm{~m} 3$ of irrigation water were applied as $35 \& 20 \& 30 \& 15 \%$ Values followed by the same letter (s) are not significantly different at $5 \%$ level

Table 12. Effect of irrigation water management and Silicon spraying on Total Acidity \% of Kitt mango trees during 2015 and 2016 seasons

\begin{tabular}{|c|c|c|c|c|c|}
\hline \multirow{3}{*}{ Treatments } & \multicolumn{4}{|c|}{2015 Season } & \multirow{3}{*}{ Mean } \\
\hline & \multicolumn{4}{|c|}{ Silicon spraying PPm } & \\
\hline & Without & 500 & 1000 & 2000 & \\
\hline Irrigation 1 & $0.68 \mathrm{a}$ & $0.68 \mathrm{a}$ & $0.66 \mathrm{a}$ & $0.65 \mathrm{a}$ & $0.68 \mathrm{~A}$ \\
\hline Irrigation 2 & $0.66 \mathrm{a}$ & $0.60 \mathrm{a}$ & $0.62 \mathrm{a}$ & $0.63 \mathrm{a}$ & $0.63 \mathrm{~A}$ \\
\hline Irrigation 3 & $0.65 \mathrm{a}$ & $0.61 \mathrm{a}$ & $0.62 \mathrm{a}$ & $0.63 \mathrm{a}$ & $0.63 \mathrm{~A}$ \\
\hline \multirow[t]{2}{*}{ Mean } & $0.66 \mathrm{~A}$ & $0.63 \mathrm{~A}$ & $0.63 \mathrm{~A}$ & $0.64 \mathrm{~A}$ & \\
\hline & \multicolumn{4}{|c|}{2016 Season } & \\
\hline Irrigation 1 & $0.59 \mathrm{a}$ & $0.59 \mathrm{a}$ & $0.57 \mathrm{a}$ & $0.57 \mathrm{a}$ & $0.58 \mathrm{~A}$ \\
\hline Irrigation 2 & $0.58 \mathrm{a}$ & $0.52 \mathrm{a}$ & $0.52 \mathrm{a}$ & $0.53 \mathrm{a}$ & $0.54 \mathrm{~A}$ \\
\hline Irrigation 3 & $0.58 \mathrm{a}$ & $0.53 \mathrm{a}$ & $0.53 \mathrm{a}$ & $0.54 \mathrm{a}$ & $0.55 \mathrm{~A}$ \\
\hline Mean & $0.58 \mathrm{~A}$ & $0.55 \mathrm{~A}$ & $0.54 \mathrm{~A}$ & $0.55 \mathrm{~A}$ & \\
\hline
\end{tabular}

Irrigation 1= $4000 \mathrm{~m} 3$ of irrigation water were applied as $15 \& 20 \& 40 \& 25 \%$ Irrigation 2= $4000 \mathrm{~m} 3$ of irrigation water were applied as $30 \& 15 \& 35 \& 20 \%$ Irrigation 3= $4000 \mathrm{m3}$ of irrigation water were applied as $35 \& 20 \& 30 \& 15 \%$ Values followed by the same letter (s) are not significantly different at $5 \%$ level 

injury and improvement yield of kitt mangos

Table 13. Effect of irrigation water management and Silicon spraying on Ascorbic acid of Kitt mango trees during 2015 and 2016 seasons

\begin{tabular}{|c|c|c|c|c|c|}
\hline \multirow{3}{*}{ Treatments } & \multicolumn{4}{|c|}{2015 Season } & \multirow{3}{*}{ Mean } \\
\hline & \multicolumn{4}{|c|}{ Silicon spraying PPm } & \\
\hline & Without & 500 & 1000 & 2000 & \\
\hline \multirow{5}{*}{$\begin{array}{l}\text { Irrigation } 1 \\
\text { Irrigation } 2 \\
\text { Irrigation } 3 \\
\text { Mean }\end{array}$} & $46.1 \mathrm{e}$ & $47.2 \mathrm{de}$ & $48.8 \mathrm{de}$ & $49.2 \mathrm{~cd}$ & \multirow{5}{*}{$\begin{array}{l}47.83 \mathrm{~B} \\
51.85 A \\
51.18 A\end{array}$} \\
\hline & $47.9 \mathrm{de}$ & $51.3 b-d$ & $57.7 \mathrm{de}$ & $50.5 \mathrm{~cd}$ & \\
\hline & 48.2 de & $53.9 \mathrm{~b}$ & $52.6 \mathrm{bc}$ & $50.0 \mathrm{~cd}$ & \\
\hline & $47.3 \mathrm{C}$ & $50.8 \mathrm{~B}$ & $53.0 \mathrm{~A}$ & $49.9 \mathrm{~B}$ & \\
\hline & \multicolumn{4}{|c|}{2016 Season } & \\
\hline Irrigation 1 & $44.6 \mathrm{f}$ & 45.9 ef & $48.1 \mathrm{de}$ & $50.3 \mathrm{~cd}$ & \multirow{4}{*}{$\begin{array}{l}\text { 47.23 B } \\
51.93 \text { A } \\
51.35 \text { A }\end{array}$} \\
\hline Irrigation 2 & $47.2 \mathrm{de}$ & $53.2 \mathrm{bc}$ & $56.7 \mathrm{a}$ & $50.6 \mathrm{~cd}$ & \\
\hline Irrigation 3 & 46.7 ef & $52.8 \mathrm{bc}$ & $54.3 a b$ & $51.6 \mathrm{bc}$ & \\
\hline Mean & $41.1 \mathrm{C}$ & $50.6 \mathrm{~B}$ & $53.0 \mathrm{~A}$ & $50.8 \mathrm{~B}$ & \\
\hline
\end{tabular}

Irrigation 1= $4000 \mathrm{~m} 3$ of irrigation water were applied as $15 \& 20 \& 40 \& 25 \%$ Irrigation $2=4000 \mathrm{~m} 3$ of irrigation water were applied as $30 \& 15 \& 35 \& 20 \%$ Irrigation $3=4000 \mathrm{~m} 3$ of irrigation water were applied as $35 \& 20 \& 30 \& 15 \%$ Values followed by the same letter (s) are not significantly different at $5 \%$ level

Interaction values were significant in most cases, high interaction value of ascorbic acid (57.7 and $56.7 \mathrm{mg} / 100 \mathrm{~g} \mathrm{F.wt}$ ) were recorded with irrigation program No.2 and 1000 ppm silicon spraying. However, least interaction value was recorded by irrigation 1 without silicon spraying in both seasons

Application of silicon (Si) in the form of potassium silicate at $0.2 \%$ reduced total acidity compare to the untreated Anna apple fruits Tarabih et al (2014). Also, improved and enhanced TSS, vitamin C. and total sugar content of Keitt mango trees fruit (Abd-El-Rahman 2015 and Zaen El-Deen et al 2015).

Research has shown that the interruption of irrigation on mango crops during the flower differentiation is an interesting option; however, the irrigation should be restarted soon after, in the panicle emergence stage. (Santos, et al 2014) Fruit soluble solids, soluble sugars and starch content were gradually increasing during fruit growth and development process Therefore, adequate irrigation can reduce soluble solids content of fruit through dilution effect of soluble solids (Sanchez et al 1989 and Junya et al 2017)

Nagle et al (2010) reported that adequate irrigation can increase mango water content of fruit, dilute soluble solids, increasing water content of fruit can lead to lower soluble solids at harvest, the same as our result. Titratable acid of fruit of each treatment gradually increases and then gradually decreases during fruit growth process which is similar to those found by Madigu et al (2009).

\section{REFERENCES}

A.O.A.C. 2005. Official Methods of Analysis A.O.A.C. $14^{\text {th }}$ ed. Benjamin Franklin station Washington DC, USA, pp. 494- 510.

Abbasi, K.S., Anjum, N., Sammi, S., Masud, T. and Ali, S. 2011. Effect of Coatings and Packaging Material on the Keeping Quality of Mangoes (Mangifera indica L.) Stored at Low Temperature. Pak. J. Nutr., 10(2), 129-138.

Abd-El-Rahman, M.M. 2015. Relation of spraying silicon with fruiting of Kitte mango trees Growing under Upper Egypt conditions. Stem Cell, 6(2), 1-5.

Abou-Baker, N.H., Abd-Eladl, M. and Abbas, M.M. 2011. Use of Silicate and Different Cultivation Practices in Alleviating Salt Stress Effect on Bean Plants Australian J. of Basic and Applied Sci., 5(9), 769-781.

Al-Wasfy, M.M. 2013. Response of Sakkoti date palms to foliar application of Royal jelly, silicon and vitamins B J. of Amer. Sci. 9(2), 315-321.

Allen, D.J. and Ort, D.R. 2011. Impacts of chilling temperatures on photosynthesis in warmclimate plants. Trends Plant Sci., 6, 36-42.

Al-Rawahy, S.A., Al-Dhuhli, H.S., Prathapar, S. and AbdelRahman, H. 2011. Mulching Material Impact on Yield, Soil Moisture and Salinity in Saline-irrigated Sorghum Plots. International J. of Agric. Research, 6(1), 75-81. 
Alvarez, J. and Datnoff, L.E. 2001. The economic potential of silicon for integrated management and sustainable rice production. Crop Prot. 20, 43 - 48.

Attalla, A.M. Abdel-Sattar, Mahrous, E. and Abdel-Azeez, A.A. 2011. Olive Trees Productivity in Response to Supplemental Irrigation under North-Western Coastal Conditions in Egypt American-Eurasian J. Agric. \& Environ. Sci., 11(5), 609-615.

Baiea, M.H., El-Sharony, T.F. and Abd ElMoneim, A.A. 2015. Effect of different forms of potassium on growth, yield and fruit quality of mango cv. Hindi International J. of Chem. Tech. Research. 8(4), 1582-1587.

Boese, S.R., Wolfe, D.W. and Melkonian, J.J. 1997. Elevated CO2 mitigates chilling-induced water stress and photosynthetic reduction during chilling // Plant, Cell and Environment. 20(5), 625-632.

Broadley, M., Brown, P., Cakmak, I., Ma, J.F., Rendngel, Z. and Zhao, F.P. 2011. Beneficial, elements. In: Marschner's Mineral Nutrition of Higher Plants. Marschner P. (eds.). Academic Press, UK, London pp. 249-269.

Brouwer, C., Goffeau, A. and Heibloem, M. 1985. Irrigation Water Management: Training Manual No. 1-Introduction to Irrigation; Food and Agriculture Organization of the United $\mathrm{Na}$ tions: Rome, Italy,

Caspari H.W., Behboudian, M.H. and Chalmers, D.J. 1994. Water use, growth, and fruit yield of 'Hosui' Asian pears under deficit irrigation. J. Amer. Soc. Hort. Sci., 119, 383-388.

Chen, N.M. and Paull, R.E. 1986. Development and prevention of chilling injury in papaya fruits (Carica papayaL.). J. Am. Soc. Hort. Sci. 111, 639-643

Dallagnol L.J., Rodrigues, F.A., Tanaka, F.A., Amorim, L. and Camargo, L.E. 2012. Effect of potassium silicate on epidemic components of powdery mildew on melon. Plant Pathology, 61, 323-330.

Datnoff, L.E. and Snyder, G.H. 2001. Silicon in agriculture. Elsevier Publisher, London

Davies W.J., Bacon M.A., Thompson D.S., Sobeih W. and Rodriguez, L.G. 2000. Regulation of leaf and fruit growth in plants growing in drying soil: exploitation of the plants' chemical signalling system and hydraulic architecture to increase the efficiency of water use in agriculture. J. Exp. Bot. 51, 1617-1626.

Ehrlich H.L. 1981. Geomicrobiology. Marcel Dekker Inc., New York, USA, 393 p.
Elahe, S., Shoushtari, R.V. and Madani, H. 2016. The Influence of Tetranychus urticae Koch (Acari: Tetranychidae) Life Table and Reproductive Parameters by Applying Si on Bean at Library Condition. Advances in Entomology, 4, 260-267.

Epstein, E. and Bloom, A.J. 2003. Mineral Nutrition of Plant, Principles and Perspectives. 2nd Ed. John Wiley \& Sons, New York, USA, pp. 1-120.

Garstka M., Venema, J.H., Gieczewska, K., Rosiak, M., Kierdaszuk, B. and Vredenberg, W.J. 2007. Contrasting effect of dark-chilling on chloroplast structure and arrangement of chlorophyll-protein complexes in pea and tomato: plants with a different susceptibility to nonfreezing temperature// Planta., 226(5), 11651181.

Grattan, S.R., Berenguer, M.J., Connell, J.H., Polito, V.S. and Vossen, P.M. 2006. Olive oil production as influenced by different quantities of applied water. Agric. Water Management, 85, 133-140.

Guntzer F., Keller, C. and Meunier, J.D. 2011. Benefits of plant silicon for crops: a review. Agronomy for Sustainable Development, 32, 201-213.

Habibi, G. 2014. Silicon supplementation improvesdrought tolerance in canola plants. Russian J. of Plant Physiology, 61(6), 784-791.

Hattori, T., Inanaga, S., Araki, H., An, P., Mortia, S., Luxova, M. and Lux, A. 2005. Application of silicon enhanced drought tolerance in sorghum bicolor. Physiolgia Plantarum. 123, 459 - 466.

Hilhorst, M.A., Dirksen, C., Kampers, F.W. and Feddes, R.A. 2001. Dielect ric relaxation of bound water versus soil matric pressure. Soil Science Society of America J. 65, 311 - 314.

Hossain, A.K. 1994. Production Technology of Mango; Horticulture Research Centre, BARI: Gazipur, Bangladesh,. 122 p.

Jackson, M.L. 1973. Soil Chemical Analysis Prentice Hall of India Private, LTD, New Delhi, India.

Junya, W., Liu, G., Liu, D. and Chen, Y. 2017. Influence of irrigation during the growth stage on yield and quality in mango (Mangifera indica L) PLoS One.; 12(4), 334-341.

Kato Y., Okami, M. and Katsura, K. 2009. Yield potential and water use efficiency of aerobic rice (Oryzasativa L.) in Japan. Field Crops Research.113(3), 328-334. 

injury and improvement yield of kitt mangos

Krause, G.H. 1994. Photoinhibiton induced by low temperature. In Photoinhibiton of Photosynthesis. From Molecular Mechanisms to the Field. Eds. N.R. Baker and J.R. Bowyer. BIOS Scientific Pub- lishers, Oxford, pp. 331-348.

Liu G.Y., Yu, E.G., Wei, J.Y., Chen, Y.Y. and Liu, D.B. 2014. Relationship between leaf water content and soil moisture in two mango cultivars. Jiangsu Agricultural Sciences. J. 42(2): $124 \pm 126$.

Liu, Z.T., Luo, G.X., Wang, J. and Chen, Y.Q. 2007. Effects of water on the growth and fruit quality of mango. J. China Tropical Agric., 1, 32-33.

Lutze, J.L., Roden, J.S., Holly, C.J., Wolfe, J., Egerton, J.J. and Ball, M.C. 2002. Elevated atmospheric (CO2) promotes frost damage in evergreen tree seedlings. Plant Cell Environ., 21, 631-635.

Ma, J.F. and Yamaji, N. 2006. Silicon uptake and accumulation in higher plants. Trends in Plant Sci., 11, 342-397.

Madigu, N.O., Mathooko, F.M., Onyango, C.A., Kahangi, E.M. and Owino, W.O. 2009. Physiology and Quality Characteristics of Mango (Mangifera indica L.) Fruit Grown under Water Deficit Conditions. J. Acta Hort, 837, 299-304.

Marschner, H. and Cakmak, I. 1989. High light intensity enhances chlorosis and necrosis in leaves of zinc, potassium, and magnesium deficient bean (Phaseolus vulgaris) plants. J. Plant Physiol. 134, 308-315.

Marschner, H. 1986. ineral Nutrition of Higher Plants. Orlando, FL: Academic Press

Marschner, H. 1995. Mineral nutrition of higher plants.Acedemic Press, London, UK.

Matoh, T., Murata, S. and Takahashi, E. 1991. Effect of silicate application on photosyntheis of rice plants (in Japanese). Jpn. J. Soil Sci. Plant Nutr. 62, 248 - 251.

Mattar, M.A. 2007. Irrgation systems effect on growth and productivity in Mango orchard Misr J. Ag. Eng., 24(1), 103-121.

Melo, S.P., Korndorfer, G.H., Korndorfer, C.M., Lana, R.M. and Santan, G.D. 2003. Silicon accumulation and water deficit tolerance in grasses. Scientia Agricola. 60, 755- 759.

Michelle, C. 2010. Frost/Cold Injury and Wind Damage to Young Vegetable Plants and Strawberries. Plant \& Pest Advisory, 16(7), 1-9.

Nagle, M., Mahayothee, B., Rung, P., Janjai, S. and Muller, J. 2010. Effect of irrigation on near-infrared (NIR) based prediction of mango maturity J. Scientia Horticulturae, 125, 771774.

Nijjar, G.S. 1985. Nutrition of fruit-trees. Published by Kaylyani, publishers, New Delhi, India.

Patumi, M., d'Andria, R., Marsilio, V., Fontanazza, G., Morelli, G. and Lanza, B. 2002. Olive and Olive oil quality after intensive monocone olive growing (Olea europaea L., cv. Kalamata) in different irrigation regimes. Food Chem. 77, 27- 34.

Perdro, V.A., Bernardo, B.S. and Vicente, P.R. 2003. Water requirements of irrigated mango orchards in northeast Brazil. Agric. Water Management 58, 241-254.

Powles S.B., Berry, J.A. and Bjorkman, O. 1983. Interaction between light and chilling temperature on the inhibition of photosynthesis in chilling-sensitive plants. Plant Cell Environ 6,117-123.

Prakash M. and Ramachandran, K. 2000. Effects of chemical ameliorants in brinjal (Solanum melongena L.) under moisture stress conditions. F.A.O. Irrigation and Drainage, 3 p.

Pregl, F. 1945. Quantitative organic micro - analysis Univ., $\left(4^{\text {th }}\right.$ ed.) 7 \& A. Churchill LTD. London.

Qin, Z. and Tian. S.P. 2009. Enhancement of biocontrol activity of Cryptococcus laurentii by Silicon and the possible mechanisms involved. Phytopathology, 95, 69-75.

Raison, J.K. and Brown, M.A. 1989. Sensitivity of altitudinal ecotypes of the wild tomato Lycopersicon hirsutum to chilling injury. Plant Physiol., 91, 1471-1475.

Rizwan M., Meunier, J.D., Miche, H. and Keller, C. 2012. Effect of silicon on reducing cadmium toxicity indurum wheat (Triticum turgidum L. cv. Claudio W.) grown in a soil with aged contamination. J. of Hazardous Materials, 209, 326334.

Rodrigues, F.A., Duarte, H.S., Domiciano, G.P., Souza, C.A., Korndörfer, G.H. and Zambolim, L. 2009. Foliar application of potassium silicate on the control of soybean rust. Australas. Plant Pathol. 38, 16-22.

Sanchez blanco M.J., Torrecillas, A., Leon, A. and Amoret, F.D. 1989. The effect of different irrigation treatments on yield and quality of verna lemon. J. Plant and Soil 120, 299-302.

Santos, M.R. and Martinez, M.A. 2013. Soil Water Distribution and Extraction by "Tommy Atkins" Mango (Mangiferaindica L.) Trees under Different Irrigation Regimes. Idesia, 31, 716. 
Santos, M.R., Martinez, M.A., Donato, S.L. and Coelho, E.F. 2014. Fruityieldand Root System Distributionof "Tommy Atkins" Mango Underdifferentirrigation Regimes. Revista Brasileira de Engenharia Agrícola e Ambiental, 18, 362369.

Singh, Z. 2005. Embryo abortion in relation to fruit size, quality, and concentrations of nutrients in skin and pulp of mango. J. Plant Nutr. 28, 1723-1737.

Smith, M.W., Kenworthy, A.L. and Bedford, O.L. 1979. The response of fruit trees to injection of nitrogen through a trickle irrigation system. J. Amer. Soc. Hort. Sci., 104, 311-313.

Snedecor .G.W. and Cochron, W.G. 1980. Statistical Methods $5^{\text {th }}$ Ed. lowa, Univ., Press Amer. lowa. USA, pp. 5-7.

Sonobe K., Tsuji, W., Kawamura, A.E., Tanaka, K. and Inanaga, S. 2011. Effect of silicon application on sorghum rootresponses to water stress. J. of Plant Nutrition, 34, 71-82.

Sonoike K. 1998. The role of low soil temperature in the inhibition of growth and PSII function during dark chilling in soybean genotypes of contrasting tolerance. Physiologia Plantarum, 131(1), 89-105.

Tarabih, M.E., El-Eryan, E.E. and El-Metwally, M.A. 2014. Physiological and pathological impacts of potassium silicate on storability of Anna apple fruits. American J. of Plant Physiology, 9(2), 52-67.
Truog, E. and Meyer, A.H. 1929. Improvement in the denige's colorimetric method for phosphours and arsenic. Ind. Eng. Anal. Ed., 1, 481-488.

Waraich, E.A., Amad, R., Ashraf, M.Y. and Ahmad, M. 2011. Improving agricultural water use efficiency by nutrient management. Acta Agriculturae Scandinavica, 61, 291-304.

Wilde, S.A., Cory, R.B., Lyer, J.G. and Voigt, G.K. 1985. Soils and Plants Analysis for Tree cultures. OxforlBH, New Delhi, India, pp. 94105.

Yamori W., Noguchi, K., Hikosaka, K. and Terashima, I. 2009. Cold-tolerant crop species have greater temperature homeostasis of leaf respiration and photosynthesis than coldsensitive species // Plant and Cell Physiology, 50(2), 203-215.

Yoshida, R., Kanno, A., Sato, T. and Катеуa, T. 1996. Cool temperature-induced chlorosis in rice plants. 1. Relationship between the induction and a disturbance of etioplast development. Plant Physiology, 110(3), 997-1005.

Zaen El-deen, E.M., Laila Attia, M.F., Haggag, F., Shahin, M.F. and Merwad, M.A. 2015. Soil Mulching and Foliar Anti-transpirations Effect on Soil, Growth and Nutrients Status of Young Mango Trees Cultivated in Toshka. International J. of Agric. Technology, 11(4), 10131032.

Zhu Y. and Gong, H. 2014. Beneficial effects of silicon on salt and drought tolerance in plants. Agron. Sustain. Dev. 34, 455-472. 